\title{
Eating to save wild-life: is a truly conservation-minded zoo/aquarium a vegan zoo/aquarium?
}

Gjerris, Mickey ; Birkved, Morten; Gamborg, Christian ; Brando, S.

\section{Published in:}

Food futures: ethics, science and culture

Link to article, DOI:

http://dx.doi.org/10.3920/978-90-8686-834-6_58

Publication date:

2016

Document Version

Peer reviewed version

Link back to DTU Orbit

Citation (APA):

Gjerris, M., Birkved, M., Gamborg, C., \& Brando, S. (2016). Eating to save wild-life: is a truly conservationminded zoo/aquarium a vegan zoo/aquarium? In Food futures: ethics, science and culture (pp. 381-386). Wageningen Academic Publishers. https://doi.org/10.3920/978-90-8686-834-6 58

\section{General rights}

Copyright and moral rights for the publications made accessible in the public portal are retained by the authors and/or other copyright owners and it is a condition of accessing publications that users recognise and abide by the legal requirements associated with these rights.

- Users may download and print one copy of any publication from the public portal for the purpose of private study or research.

- You may not further distribute the material or use it for any profit-making activity or commercial gain

- You may freely distribute the URL identifying the publication in the public portal 


\title{
Eating to save wild-life Is a truly conservation-minded zoo/aquarium a vegan zoo/aquarium?
}

\author{
M Gjerris *, M Birkved**, C Gamborg* \& S Brando *** \\ * Department of Food and Resource Economics, University of Copenhagen \\ **Department of Management Engineering, Division for Quantitative Sustainability \\ Assessment, Technical University of Denmark \\ *** AnimalConcepts, Zoom 1813, 8225 KM Lelystad, The Netherlands
}

\begin{abstract}
According to the European Association of Zoos and Aquaria (EAZA, 2016) their mission is "to facilitate cooperation...towards the goals of education, research and conservation". Livestock production is one of the leading causes of often-irreversible land use changes, greenhouse gas emissions, loss of biodiversity and different types of environmental degradation - all affecting wildlife negatively, and hence undermining conservation policies that aim to protect individuals, populations and species. But what is the link between livestock production and zoos and aquariums? One link, putting it a bit boldly, could be: Does it make sense to work for conservation by preserving animal species in captivity while selling food to visitors that may be undermining this effort? Complicating the issue is that zoos and aquariums are dependent on generating a profit from "non-core" services such as cafeterias and the like to generate funds for running the zoo, and conceivably, in turn for conservation purposes - funds that might diminish if zoos and aquariums do not sell a variety of food products, including animal-based ones to their visitors. The main question addressed by this paper is: If zoos and aquariums are to work for sustainability and species conservation should food served in zoos be part of considerations - and to what extent? To answer this question the paper presents the goals of EAZA along with environmental impact profiles, relying on previously published life cycle assessments of the entirety (i.e. from cradle to gate) and across a multitude of impact categories (i.e. including and beyond climate change), of typical food items sold in zoos and aquariums. It describes the impacts on wildlife and nature that these products may have. Further we link this analysis to different ideas of sustainability, addressing the issue of how to balance positive and negative impacts of zoos and aquariums. Finally we discuss the educational opportunities that arise if food served in zoos and aquariums is seen as part of a conservation strategy - and the possible challenges such an approach faces.
\end{abstract}

\section{Keywords}

climate change, ethics, food, habitat loss, life cycle assessment

\section{1: Introduction}

Climate change has, and is most likely to have, widespread effects on wildlife due to especially changing weather patterns, environmental degradation and habitat loss (Bellard et al. 2012). Human population growth and logging, fossil fuel extractions, as well as mining are known to threaten wildlife and their habitats. Climate change, however, has added a new urgency into the efforts to protect and conserve the biodiversity of the planet. One organization that for many years has worked with species conservation and raising public awareness around these issues is the European Association of Zoos and Aquaria (EAZA) through the collaboration of 377 zoos and aquariums in Europe and the Middle East, with an estimated 140 million people visit EAZA member zoos and aquariums annually. The goal and strategy of EAZA regarding species conversation are very visible on their website: 
"Our approach to species conservation, called the One Plan approach, recognises that zoos and in situ conservationists need not only to work together to protect animals, but also to engage the public of their communities to take the lead in demanding action from authorities, governments, corporations and themselves so that together we can reduce the stress on endangered species and their habitats" (EAZA 2016).

EAZA's ideals of collaboration and reducing the stress on species and their habitats through the work of zoos and aquariums within conservation policy and efforts may contribute to help to protect animals and their environment. Our question is: Does the food served in zoos and aquariums have anything to do with this? This paper examines what a sustainable zoo or aquarium might entail and gives a short overview of food typically served in zoo and aquarium restaurants and snack stands. With Life Cycle Analysis of these commonly served food items we intend to shed light on the effects of production and consumption of animal protein (including fish) on wildlife and their habitats. We conclude with discussing how to meet the aforementioned ideals of protecting animals and their environment could be linked to food choices presented to visitors at zoos and aquariums.

\section{2: What does being a sustainable zoo/aquarium include?}

The notion of sustainability has been widely accepted as a broad and inclusive political (value-based) as well as managerial (practical) framework (Gamborg and Sandøe 2005a). One of the reasons for this is that it seemingly represents a more unified view rather than polarized discussions with either a one-sided focus on effectiveness or profit on the one hand, or uncompromising demands for conservation, animal welfare - or what other concern may be felt relevant. In many ways, sustainability has become another word for 'the good' or the ethical 'right' thing (although, naturally what is good and right depend on one's values and ethical positions).

Zoos and aquariums could be seen as a kind of animal husbandry, albeit with a focus on edutainment and breeding animals for conservation, instead of production. To further animal stewardship, including inspiring to sustain species, they seek to create a reverence for wildlife population and more broadly to care for nature (Conway 1995). There are many ethical parameters to ponder in the running of a sustainable sensu lato zoo or aquarium ranging from profitability, animal acquisition, care, breeding, culling, and individual and population level welfare to wildlife, nature conservation and environmental impact and social responsibility. Clearly, a lot of these issues have been, and are addressed in attempts to build sustainable zoos and aquariums.

However, problems abound when trying to decide which elements to include, and possibly 'tweak', when to trying to become more sustainable. Although sustainability is presented as the amalgamation of three main spheres: economic, environmental, and social, there are different interpretations and different ways to balance these areas (Söderbaum 2014). Some have argued that he concept of sustainability is prone to being shaped according to the interests at play (Maxey 2007). In any event, it seems fair to say that what is considered sustainable depends on the underlying 'weak' or 'strong' interpretation, which in turn rest on a number of underlying values, including who (or what) to include as to be of concern (Gamborg and Sandøe 2005b). One of the many things to discuss would be the wider environmental impact of the kinds food served in zoos and aquariums.

Many zoos and aquariums have chosen to enter certification and accreditation schemes and to some extent (at least indirectly) the balancing has been decided upon by the certifying 
organization. Often, it entails promoting local, organic, seasonal, fair-trade products, and certified chains of custody, such as MSC seafood and FSC wood. The question is, however, whether reliance or at least inclusion of animal protein, 'sustainably' sourced or not, is, in the broader perspective sustainable - enough - given the documented environmental impacts?

\section{3: Catering in zoos/aquariums}

A statement sometimes uttered by zoo directors or finance executives responsible for the economic running of a zoo suggests that zoos can be seen as a restaurant with animals. Money is made by sales of food, drinks and snacks while animals and staff only cost money. Zoos and aquariums have many costs such as hiring staff, feeding and caring for the animals, advertising, research, education and conservation programs. The sales of food, drinks and snacks as well as interactive programmes, photo and feeding opportunities, and souvenirs are important sources of income. Today, many zoos and aquariums offer a wide variety of food choices, from small snacks (e.g. hot dogs and popcorn), fast food such as hamburgers and fries to seated dinners and fancy buffet catering for wedding and dinner parties. Menus are often adapted to reflect a theme within the zoo, like "Asian", "South American" or "African", including meat, fish, vegetables, eggs, dairy products and even tofu with flavours spanning from curry to chilli. The food served varies from country to country: from baked potatoes with beans, to pizza and pickled herring. It is important to note that many zoos and aquariums outsource the catering; from the restaurants to the hotdog stands. Therefore, many zoos and aquariums have only little or no control over what types of food are offered to the visitors. The question is, however, whether the wide variety of food sold in zoos and aquariums could be used more actively to promote the outspoken goal of EAZA of contributing to species conservation?

\section{4: Life Cycle Analysis of catering in zoos/aquariums}

Evaluating the environmental performance of food possesses a considerable challenge in terms of assessment approach. All steps in the value chain of food from farming, processing, transport, use and disposal to different extent and in different ways impact on the environment (i.e. some steps may mainly contribute to global warming while others may primarily contribute to toxicity related impact categories). To account for the impacts related to food it is hence necessary to account for as many as possible of the activities in the value chains of food items - and also to account for the diversity of impacts related with food consumption. The methodology of Life Cycle Analysis seeks to account for all this and includes a multitude of environmental impact categories (Goedkoop et al. 2008), of which most are relevant for food consumption. Despite the fact that the life cycle of food contributes to all impact categories typically accounted for in LCAs, most often only the contribution to global warming is reported; which is the reason for focussing on this impact category in this paper.

Food is an important contributor to the overall impact of consumption. As presented by Kalbar et al. (2016) the contribution from food consumption to the overall impact pattern from consumption among Danish citizens ranges across the 18 covered impacts categories between 0.3 and $94.6 \%$ of the total consumption related impact profiles on person level. The results presented by Kalbar et al. (2016) indicate that food consumption may be a significant segment to consider when trying reducing the overall environmental burden resulting from consumption. For global warming, food consumption accounts on average for $16.4 \%$ of the burden resulting from consumption (covering impacts related to consumption of food, various transport forms, accommodation and various energy carriers), and food is hence in the top 3 of the consumption segments with the largest global warming contributions. Different food items are associated with different environmental burdens. Foster et al. (2006) reveal that the 
burden difference between e.g. potato and beef compared on a mass basis amounts to a factor $>60$ in terms of climate burden, meaning that the contribution to global warming of $1 \mathrm{~kg}$ beef is 60 times larger than the contribution from $1 \mathrm{~kg}$ of potatoes in terms of global warming accounted for over a 100 year period.

Meat and in particular beef are some of the most burdensome meal ingredients from a climate perspective. Consumers may therefore ask themselves if switching meat types may improve the environmental performance of an average meal or if they should fully or partially (e.g. as known from week day vegetarians) abandon meat consumption in order to reduce the environmental impacts related with food intake. The results presented by Foster et al. (2006) indicate that comparing the global warming performance of sheep, beef, pork and poultry on a weight basis sheep and beef are the most burdensome while poultry is the least burdensome meat type. As the results presented by Foster et al. (2006) also indicate, the global warming contribution of poultry is still 6-22 times higher than that of plant protein based food items such as potatoes and bread when compared on weight basis. This indicates that selecting between different meat types may reduce the impacts from meals to a considerable extent, however not as much as leaving out the meat items completely.

Since different food items obviously have quite different impact profiles the question remains how these differences are manifested in our choice of food items or rather through our diets. As presented by Goldstein et al. (2016) there are considerable (approximately 50\% reduction) global warming savings to be achieved by changing from an omnivorous diet to a vegetarian diet. Moreover, there appears to be a saving by changing from a vegetarian to vegan diet but this saving is less significant.

Overall, meat consumption is associated with considerable higher global warming contributions than consumption of food items based on plant protein (Foster et al. 2006; Goldstein et al. 2016). The issues relating to the environmental burden of food presented here all indicate that the relation between human nutrition and wildlife conservation is complex, to say the least. It involves a number of trade-offs between life cycles stages of food. Saving food waste reduces the demand for agricultural production - hence a trade-off between the disposal and manufacturing life cycle stages and impact categories. Reduced meat consumption compensated for by increased vegetable consumption will lead to a lower climate burden from human nutrition as presented by Goldstein et al. (2015) will most likely be counterbalanced by an increased/altered pesticide use potentially leading to an increase in toxicity related impacts related to conventional agricultural production. As zoos and aquariums generally seek to attract people with an interest in wildlife and conservation, combining a general conservation interest of the zoo/aquarium audience and the consumer's role in being part of reducing the environmental burden related with (food consumption, zoos and aquariums seem to have a role to play as they might provide targeted visitor "education" through different strategies.

\section{5: Effects of production and consumption of animal protein on wildlife}

Meat production substantially influences the environment (Gamborg and Gjerris 2012) in terms of direct and immediate effects (e.g. clearing of woodland for pastures) or indirect and long-term effects (such as land subsequent land use changes or emission of greenhouse gases) at local and global scales (Ilea 2009). Studies have shown that agriculture is responsible for $70 \%$ of global freshwater consumption, which thus puts scarce water resources under pressure. Livestock production takes up more than $65 \%$ of all arable land and hereby contributes to deforestation, changes in savannahs, drainage of wetlands and desertification 
(Norris et al. 2010). Evidently some of these areas affected host a number of species and thus biodiversity conservation is related to climate change both directly and indirectly. The estimated contribution of the livestock sector to the humanly caused GHG emissions is $18 \%$ according to FAO (Steinfeld et al. 2006), while others estimate a contribution as high as 50\% (Goodland \& Anhang 2009). Educated guesses are that almost a doubling in consumption of animal products can be expected by 2050 .

\section{6: Including catering in the sustainability concept: Opportunities and challenges}

Assuming that zoos and aquariums, besides entertaining, wish to promote conservation of wildlife, they often do this by seeking to create understanding and awe in the visitors - and, in turn, may raise money for conservation efforts. Zoos and aquariums work together on breeding programmes for endangered species, conduct research and participate in local attempts to preserve wildlife habitats etc. However, as one of the threats to current wildlife populations is the loss of habitats, land use changes and changing climate patterns, and it is hard to deny that human diet plays a role in this, it may seem counter-productive to try to engage visitors in efforts to save wildlife at the same time as offering hamburgers and other animal protein based food products.

First, as shown in section 4, a higher environmental impact arises from eating meat and dairy products than from products based on plants. Still, considering the amount of meals served in zoos and aquariums each year compared to the total amount of human emissions, the human climate impact would not change significantly, even if all zoos and aquariums only served vegetarian or vegan meals. In the current situation with rapidly rising temperatures, however, one could argue that any contribution, however small, is important. Here, however, we will draw attention to the educational potential of including the food served to visitors in zoos and aquariums as part of a conservation strategy. Through what is served, it is possible to highlight that a diet based more on plant protein is necessary if we are to lower emissions and not run the risk of seeing the animals that we have just admired in the zoo and aquarium go extinct because of climate change and habitat loss. The educational value and effect of such experiences at the zoo or aquarium might result in visitors consuming less meat and fish and/or eat more sustainably at home too.

There are obvious challenges in adopting such a strategy. Zoos and aquariums are, as mentioned above, dependent on the income from food sales to visitors. If the visitors respond negatively to initiatives that link food consumption to wildlife conservation and simply bring their own food or choose to visit other places, obviously nothing is gained. We realize this is a risk both because of expectations and dietary habits and because people might find it uncomfortable to be confronted with the negative effects of their own lifestyles on a recreational visit. Thus such initiatives need to be well-planned and communicated clearly. Further, as mentioned previously, many zoos and aquariums have outsourced food services to private companies and might find it difficult to or cannot influence what is on the menu. Thus in those situations it will take a re-thinking of the business model of catering to gain influence on the food selection available to visitors.

Nevertheless, it could be an opportunity to let visitors know about the connection between wildlife conservation and livestock production - and, at the same time, provide them with a tool to act in a situation where many express hopelessness and confusion on how to make a difference (Kim et al. 2015). Zoos and aquariums could play a role here. And although they should probably not "go vegan" from Day 1, they could consider taking the opportunity to 
inspire people to a change in diet by presenting them with information and alternative food choices.

\section{References}

Bellard C, Bertelsmeier C, Leadley P, Thuiller W and Courchamp F (2012): Impacts of climate change on the future of biodiversity. Ecology Letters 15: 365-77

Conway W (1995): Zoo conservation and ethical paradoxes. In: Norton BG, Hutchins M, Stevens EF and Maple, T.L. (Eds.), Ethics on the ark. Zoo, animal welfare and wildlife conservation. Smithsonian Institution Press: Washington and London, pp. 1-12

Doherty TJ and Clayton S (2011): The psychological impacts of global climate change.

American Psychologist, 66(4): 265-276

European Association of Zoos and Aquaria (2016): Conservation.

http://www.eaza.net/conservation/ (last accessed 22.03.16)

Foster C, Green K, Bleda M, Dewick P, Evans B, Flynn A and Mylan J (2006):

Environmental Impacts of Food Production and Consumption: A Report to the

Department for Environment Food and Rural Affairs. Defra. Manchester Business School

Gamborg C and Sandøe P (2005a): Applying the notion of sustainability - dilemmas and the need for dialogue. In: Holm S and Gunning J (eds.): Ethics, Law \& Society. Hants: Ashgate, pp. 123-130

Gamborg C and Sandøe P (2005b): Sustainability in farm animal breeding: a review. Livestock Production Science 92:221-231

Goedkoop MJ, Heijungs R, Huijbregts M, De Schryver, A, Struijs J and Van Zelm R (2009): ReCiPe 2008, A life cycle impact assessment method which comprises harmonised category indicators at the midpoint and the endpoint level. First edition Report I: Characterisation; 6 January 2009, http://www.lcia-recipe.net (last accessed 23.03.16)

Goldstein B, Hansen S, Gjerris M, Laurent A and Birkved M (2016): Ethical aspects of life cycle assessments of diets. Food Policy 59: 139-51

Goodland R and Anhang J (2009): Livestock and Climate Change. What if the key actors in climate change are... cows, pigs, and chickens. Washington DC: World Watch Institute

Ilea RC (2009): Intensive livestock farming: Global trends, increased environmental concerns, and ethical solutions. Journal of Agricultural and Environment Ethics 22:153-67

Kalbar PP, Birkved M, Kabins and Nygaard SE (2016): Personal Metabolism (PM) coupled with Life Cycle Assessment (LCA) model: Danish Case Study. Environment International (In press)

Kim B, Neff R, Santo R and Vigorito J (2015): The Importance of Reducing Animal Product Consumption and Wasted Food in Mitigating Catastrophic Climate Change. John Hopkins Center for a Livable Future.

Maxey L (2007): From "alternative" to "sustainable" food. In Maye D, Holloway and, Kneafsey M (eds.): Alternative food geographies: Concepts and debates. Elsevier: Oxford, pp. $55-75$

NASA Earth Observatory (2016): Record warmth in February. Image of the day. http://earthobservatory.nasa.gov/IOTD/view.php?id=87691 (last accessed 22.03.16)

Norris K, Potts SG and Mortimer SR (2010): Ecosystem services and food production. Issues in environmental science and technology 30: 52-69

Söderbaum P (2014): The role of economics and democracy in institutional change for sustainability. Sustainability 6: 2755-65

Steinfeld H, Gerber P, Wassenaar T, Castel V, Rosales M and de Haan C (2006): Livestock's long shadow - Environmental issues and options. Rome: Food and Agricultural Organisation of the United Nations 